\title{
Fine Art Learning Through the Implementation of the Free Expression Method in Year 11 of State Junior High School SMPN 1 Tasikmadu
}

\author{
Nur Dayo Ivory ${ }^{1}$ \\ ${ }^{1}$ Graduate School Of Arts Education, Yogyakarta State Universiy, Yogyakarta, 55281, Indonesia \\ *Corresponding author. Email: ivorynurdayo@gmail.com
}

\begin{abstract}
The Free Expression method is applied in the Fine Art subject at state junior high school SMPN 1 Tasikmadu to help teachers improve the students' creativity in drawing. The subjects involved Year 11 students in the odd semester during the academic year 2019/2020. This study was conducted to help students who were facing difficulties in the drawing class as they were unmotivated and unable to fully express themselves due to the tedious lecture-based delivery. For this reason, the teacher applied the Free Expression method so that students were able to actively express themselves in the learning activities in the class. Moreover, the Free Expression method also allowed students to understand the learning material on basic competency 4.2 more easily. Based on the result of discussion, the Free Expression method has helped teacher improve the students' creativity in the Fine Art subject for Year 11 at SMPN 1 Tasikmadu.
\end{abstract}

Keywords : Free Expression Method

\section{INTRODUCTION}

The teaching learning activity is essentially a process of interaction of a reciprocal relationship between teacher and students in a learning unit. As one of the components which hold an instrumental role in the teaching learning process, teachers serve not only to deliver the learning materials, but also as the center of learning which should be enjoyable and exciting.

As the manager and the subject in the teaching learning process, the teacher is the one who direct how the teaching learning process is conducted. For this reason, teachers must be able to make learning more effective and interesting so that the delivered learning materials make students encouraged and excited to learn. In regard to this, a teacher must be smart in selecting the appropriate learning method when dealing with challenges in the class.

Learning method is the method used by the teacher to make a relationship with students during learning [1]. The term may also refer to the learning strategy used by the teacher as a tool to achieve learning objectives. Meanwhile, the free expression method is defined as a way to teach students to express their feelings in the form of art.

This study discusses the fine art learning through the application of the free expression method in Year 11 of state junior high school SMPN 1 Tasikmadu.

Based on the background, the formulation of the problems is as follows: How is the free expression method applied in the Fine Art subject for Year 11 at SMPN 1 Tasikmadu? Can the free expression method applied in the Fine Art subject for Year 11 at SMPN 1 Tasikmadu?

This paper is expected to offer an alternative in the Fine Art subject learning method, as well as to provide additional reference and knowledge.

\section{LITERATURE REVIEW}

\subsection{Learning Method}

Teaching in an effective manner highly depends on the selection and use of the appropriate learning method. Using the right learning method allows the teaching learning process to be more enjoyable and less tedious, while simultaneously helps students to receive the knowledge more easily. 
Therefore, in selecting a learning method, one must consider the characteristics of the students and the learning materials. Different methods may be used for different classes as the learning method must be adjusted with the students' characteristics and abilities.

Generally, learning method can be defined as the way that is used to implement plan that has been established into real and practical activities to obtain the learning objectives. In other words, it refers to the way that a teacher chooses to optimize the teaching learning process which aims to achieve the expected learning goals.

Learning method is the way that is used by teachers to form a relationship with students during learning [1]. Based on this notion, it can be explained that learning method is the way that teacher uses to deliver the learning materials to achieve the learning objectives. This subsequently drives teachers to search for the appropriate learning method in delivering the learning materials so that they can be properly absorbed by the pupils.

Moreover, it needs to be noted that a good learning method must be flexible, can be adjusted to the students' characters, have functional materials which combine theory and practice, and direct students toward practical abilities. A good method should also ensure that the material is not reduced, and even have the ability to develop material instead. Moreover, students should have the opportunity to express their opinions while teacher has the respected position in the learning process.

\subsection{Fine Art Learning}

Fine art learning is integrated into the Arts and Culture subject. The objective of art education at school is to continue and develop the ability to make works of art and receive knowledge on fine art that students have had prior to entering school. It must be noted that all children have a basis of sensitivity and creativity which must be paid attention to and developed by teachers when they enter the school setting by providing a great opportunity for students in creating art as their form of expression [2].

Fine art education for students is an effort to provide basic knowledge and experience of creative art activities by applying the concept of art an educational tool. The application of the concept of art certainly must be set within an interesting and enjoyable learning condition and the atmosphere of creative playing [3]. In fine art learning, there is a competency on drawing expressions.

Drawing is a process of expressing ideas, dreams, feelings, and experiences using a certain drawing tool [3]. The development of creativity in drawing can be done in many ways; one of them is by the free expression drawing.

\subsection{Free Expression}

The Free Expression method is a method which provides students with the freedom to express their ideas or feelings into an art form without the limitations or challenges of conventional technical rules in creating drawings [4].

The free expression method is essentially a way for students to learn by expressing their feelings in the form of art. In order for this method to work optimally, the teacher needs to follow the following stages [5]:

1) Provide multiple options of themes to stimulate creativity;

2) Provide a number of options of media and materials, e.g. watercolor paint, pastel oil, ink, plaque paint, etc.;

3) Explain the characteristics of paper types and how to select the appropriate type; and

4) Explain the style of art, whether sketches or drawing.

There are several limitations to the implementation of the method of free expression based on psychological reasons. First, although education and psychology recommend freedom of expression for comprehensive development, it does not deny assistance. Secondly, it is justified that students' creative development requires careful stimulation and consideration, in the form of encouragement at each step of the learning activity [2]. Therefore, in this free expression method, the presence of teachers is still needed even though the percentage is very small.

\section{DISCUSSION}

The free expression method is used to provide flexibility for students to express their feelings in creating works of art. The process of creating art in this method starts from determining the theme, namely the content of the expressions to be conveyed; the media, namely the materials and tools selected for students to use in realizing the form of art expressions; and the style of expression, namely art expressions that are highly individual, so that each student will produce works of art in different styles or characters [5].

The free expression method is essentially a way for students to learn by expressing their feelings in the form of art. In order for this method to work optimally, the teacher needs to follow the following stages [5]:

1) Provide multiple options of themes to stimulate creativity; 
2) Provide a number of options of media and materials, e.g. watercolor paint, pastel oil, ink, plaque paint, etc.;

3) Explain the characteristics of paper types and how to select the appropriate type; and

4) Explain the style of art, whether sketches or drawing.

There are several limitations to the implementation of the method of free expression based on psychological reasons. First, although education and psychology recommend freedom of expression for comprehensive development, it does not deny assistance. Secondly, it is justified that students' creative development requires careful stimulation and consideration, in the form of encouragement at each step of the learning activity [2] Therefore, in this free expression method, the presence of teachers is still needed even though the percentage is very small. This condition is very meaningful for students who have high motivation to learn. For that, of course, the education system requires a number of tools that regulate educational activities. In terms of applying the free expression method, teachers must always uphold the freedom of responsibility [6]. Freedom of responsibility means that teachers must be able to create learning conditions that do not limit students' expressions in expression, yet still in an orderly condition. It can be concluded that the free expression method is a method that teaches students how to express ideas and feelings into works of art by applying freedom within the guidance of teacher to maintain a free and responsible condition. The fine art learning at state junior high school often experiences challenges in practice due to less suitable learning method. In this study, teachers apply the free expression method in the drawing practice learning.

The implementation of the free expression method in the Fine Art subject was done in the teaching of KD 4.2 material for Grade 11 students during the odd semester. The class begins with greetings and apperception, followed by an introduction on the basic competency and learning objectives. Next, students were presented by a visual of an illustration on drawing about the KD 4.2 material.

In the following stages, teacher would instruct students to begin drawing with free expression under teacher's supervision. Although it the instruction is to draw freely according to their expressions, students still may face a difficulty. Therefore, teacher still pays attention by going around the room to ensure that all students receive the support they need in the drawing practice process based on basic competency 4.2. At the end of the class, students are asked to show and tell their works to the class.
The application of the free expression method in learning in which students practice drawing has shown a good result. Therefore, it can be concluded that the free expression learning for basic competency 4.2 has managed to improve the learning process for both the teacher and students.

\section{CONCLUSION}

Based on the background, discussion, and result of discussion, the following conclusions are obtained.

1. The implementation of the free expression method in the Fine Art subject at state junior high school SMPN 1 Tasikmadu in Grade 11 during the Odd Semester in which students have the freedom to express their ideas in drawing tasks.

2. The freed expression method is highly suitable to apply in the Fine Art subject, as evident by how well the students perform. In addition, they are confident and expressive when presenting their works in front of the class.

\section{SUGGESTION}

It is highly essential that the learning process, especially in fine art learning, apply a suitable learning method to make the teaching learning process more enjoyable for students and stimulate their learning motivation.

\section{REFERENCES}

[1] Sudjana, Nana. "Penilaian Hasil Proses Belajar Mengajar [Result Assessment Teaching and learning process]." Bandung: PT. Remaja Rosdikarya, 2009.

[2] Muharam dan Sundariyati, W., "Pendidikan Kesenian II (Seni Rupa) [Arts Education II (Fine Arts)].".Jakarta,

Debdikbud Dikti, 1993.

[3] Sumanto, "Pengembangan Kreativitas Seni Rupa Anak Sekolah Dasar [Development of Visual Art Creativity for Elementary School Children].” Jakarta: Depdiknas, 2006.

[4] Tarigan, H.G, "Menulis Sebagai Suatu Keterampilan Berbahasa [Writing as a Language Skill]." Bandung, Angkasa, 1982.

[5] Weinger, K., Beverly, E. A., Lee, Y., Sitnokov, L., Ganda, O. P., \& Caballero, A. E.,The effect of a structured behavioral intervention on poorly controlled diabetes: a randomized controlled trial. Archives ofinternalmedicine, 171(22)(2011).DOI:10.1 001/archinternmed.2011.502

[6] Sukarya, Zakaria, dkk, "Dasar-dasar Seni Rupa [Art Basics].” Jakarta,Dirjen Dikti, 2010. 